\title{
The Effect of Board Characteristics on Corporate Social Responsibility Disclosure in the Jordanian Banks
}

\author{
Ala Hussein Albawwat \\ Department of Accounting, Faculty of Business, Amman Arab University (AAU), Amman 11953, Jordan
}

Received August 11, 2021; Revised December 14, 2021; Accepted December 27, 2021

\begin{abstract}
Cite This Paper in the following Citation Styles
(a): [1] Ala Hussein Albawwat, "The Effect of Board Characteristics on Corporate Social Responsibility Disclosure in the Jordanian Banks," Universal Journal of Accounting and Finance, Vol. 10, No. 1, pp. 286 - 297, 2022. DOI: 10.13189/ujaf.2022.100129.
\end{abstract}

(b): Ala Hussein Albawwat (2022). The Effect of Board Characteristics on Corporate Social Responsibility Disclosure in the Jordanian Banks. Universal Journal of Accounting and Finance, 10(1), 286 - 297. DOI: 10.13189/ujaf.2022.100129.

Copyright $\bigcirc 2022$ by authors, all rights reserved. Authors agree that this article remains permanently open access under the terms of the Creative Commons Attribution License 4.0 International License

\begin{abstract}
A research was conducted to assess the influence of board member characteristics on corporate social responsibility disclosure (CSRD) within banking industries in Jordan where a total number of 155 banks per annum were sampled between the years 2010 and 2020. A hundred items have been developed as a checklist to evaluate the level of disclosure and the analysed results were comparatively low in terms of the level of disclosure for the selected banks in Jordan. To test the model, data from a time series and the ordinary least squares model have indicated the influence of three (3) factors that impacted positively on the disclosure of corporate social responsibility (concerning the board's size, board of foreign members and the audit committee). The present research thereby proposed that the directorate boards of commercial banks in Jordan need to create more awareness about corporate social responsibility, and implement proper monitoring activities in disclosing information on regular by the Central Bank of Jordan. However, any commercial bank that fails to comply with the rules and regulations should be sanctioned severely for indiscipline. This study became relevant by contributing meaningfully to literature where the quality of information of the banking industries could be improved to meet the novel trend by worldwide economic analysts. Furthermore, this research successfully carried out investigations on the impacts of CSRD level within the context of a new business environment, thereby projecting more guidelines for future works in a related discipline. However, the overall outcome from this study could be made to attract groups of stakeholders and shareholders like moderators, potential
\end{abstract}

investors, and CSR and government officials.

Keywords Board Characteristics, CSR Disclosure, Banking Industry, Jordan

\section{Introduction}

From a global perspective, organizations need to create sound awareness about corporate social responsibility (CSR) in any society. It was revealed by researchers the rate at which how critical is the responsibility to their stakeholders in an organizational setting as this could insert positively to their shareholders, consumers, investors, creditors of public agencies, non-governmental organizations, and employees [8]. This act is expected from the public to be assured of the success of the organization's measures on community and social problems as detailed in their responsibilities. In a study carried out by another researcher, the authors argued that operational activities of social, legal and pressure on better regulatory approach and expectations from stakeholders allow companies to reconcile on issues regarding social and environmental factors [1]. Also, CSR was said to remain a critical issue to consider in a competitive business environment, as this tends to foster help to any organization in solving their economic problem, and meet the demands of stakeholders. It must be emphasised that CSR is an institutional move due to the level of legal constraints that could affect the interest's shareholder [50].

Considering the global financial crisis, many giants and 
well-renowned companies have collapsed, and the economic meltdown served as an eye-opener to work better on good corporate governance. The failures were manifested globally by negatively affecting potential investors to invest, and evidence of this was traced to Bank of the Commerce (Enron 2001; Adelphia 2002; World Com, 2002). However, the accounting report was also affected negatively as mentioned by [6]. In the middle of the year 2008, the worldwide financial crisis brought about much attention for a new line to studies and this, therefore, makes this study relevant. Arguably, the corporate governance of poorer nature called for the biggest firms to collapse around the globe. The financial meltdown throughout the world began to manifest in the banking industry's most especially "loan crisis" since the borrowers failed to serve their loan back and this, in turn, allowed the biggest international bank to fail [14].

The nation of Jordan, as a case sample, Al-Batra Bank collapsed in 1989, and this alerted scientists to improve the system of banking in Jordan. The bank was established in 1978 and later became the second biggest and most influential in Jordan, but it collapsed in the year 1989. The bankruptcy of banks instilled bad experiences in the Jordanian economy. It should be noted that the crisis did not only affect the financial sector of Jordan but also attracted poor deposits, loss of jobs, loss of investors and poor unemployment rate. In addition, the scandals of AlBatra Bank, three other banks (the Gulf Bank, Amman Investment Bank and Philadelphia Investment Bank) in Jordan equally experienced enormous financial meltdown which were probably traced to financial mismanagement or corruption between "2000-200". Thus, poor corporate governance attracted those banks to collapse. The JCB confronted many obstacles in their plans to avert the liquidation of the banks in question. The possible ways to get over these challenges by JCB were firstly, to restructure Gulf Bank of Jordan with new and better management at the top-notch together with a newly appointed board of directors, and secondly, to merge Amman Investment Bank, Philadelphia Investment Bank and with other banks with the aims of sustaining the economy of Jordan, building back the confidence of depositors and shareholders and sustaining the workforce of employees. Some years back around 2009, the JCB decided to get rid of the board of directors of Capital Bank because of some governance problems. It was announced by the JCB that the solvency and the financial status of the Capital Bank were much better and the reason behind their actions was precautionary due to the fact that the bank in question did not abide by the JCB guidelines in their decision-making process [14].

Banks have a major key role to play in the environmental performance and social economic impact of banks' policies to lend to other industries with the banking system. They equally perform very important activities for the economy involved in efficient and proper allocation of capital. On this note, there is a need to improve the banking industry capable of project the best performing economic system [36]. It is essential to know that the banking sector identifies that, it is a must to consider the economic benefits from every perspective, starting from legal compliance and social welfare [14]. Banks should encourage and act upon and review their ethics and the social acts in their investment and financing activities to ensure ideal protection of the integrity and legitimate interests of the stakeholders of the banks as mentioned by [1].

Currently, many amendments have been made by Jordan to regulate and the activities of CSR, to be more specific, quite several regulations were endorsed by the regulatory bodies under the Law. On a corporate social responsibility disclosure, (CSRD) for example, many circulars were brought to reflect on the disclosure of data assigned to CSR and the Circular demanded proper reports on the impacts of the environment and social aspects of businesses (Companies Control Department, 2006). There is no doubt that there is little scientific research in Jordan addressing CSRD, most especially as related to the banking sector. Therefore, the present study becomes relevant to be carried out by choosing commercial banks in Jordan.

\section{Hypotheses Development and Theoretical Background}

Corporate governance (CG) is explained as an internal measure that is adopted to manage the activities of corporate governance. It stands as a relationship between the shareholders of a company and the board of directors, including other related bodies. In a study revealed by Poudel, [47], the CG possesses the ability to create an operating mechanism capable of managing and operating certain goals for ideal monitoring of a company's performance. The CG has equally been seen as a medium by which businesses could be directed with a controlled system over long-term effects. The concept behind CG was therefore ascribed to four pillars of CG and these include: (i) responsibility, (ii) transparency, (iii) fairness and (iv) publicity. CG was also considered as a monitoring system by which financial resources are provided to bring about highly improved economic efficiency for a business environment to operate safely. They will give birth to a managing activity for better transparency of information to users and encourage the greatest benefit to shareholders [48].

Different researchers viewed the function of CSR from different perspective angles. According to Bowen [7], CSR was seen as a commitment by a corporate body on issues related to ethics. On this note, there is encouragement to reconcile the relationship between society, economy, and the community. Fairness among every party involved is also present. In another view of the study, CSR was termed as the ability of the enterprise to commit itself in its way of carrying out business activities. Such a commitment was 
meant to harmonize the interests of CSR stakeholders [1]. Furthermore, the study of Poudel [47] claimed that for a way of doing business, CSR is responsible to the organizations by ensuring better legal activities, ethical, social, and environmental processes. It is however advantageous to the stakeholders in ensuring fairness in the business community. Also, the work of Lee [1] stated that CSR was observed to be one of the adopted strategies of the business management system used in determining the economic performance and ethical values of the companies. Within the context of CG, CSRD is greatly accountable for the success of a company, as the well-being of shareholders is dependent on the potential of CSRD [66].

It has been observed that the legitimacy, agency and stakeholder theories were used in CSR and CG disclosures regularly. The theory of stakeholder holds to the fact that disclosures must meet up with needed data of various stakeholders [13]. The theory of legitimacy is in line with the company's support to form and execute environmental and social disclosures voluntarily to legalize their operations and presence [39]. Meanwhile, the theory of agency has been adopted for conflict resolution between the agents (managers) and the principals (shareholders) with the assurance that managers are joyfully motivated to reveal updated incentives [21]. Following the stakeholder-agency theory, conflicts on the agency could be relieved as soon as the managers decide on the voluntary disclosure to align the interest of every stakeholder [17]. In the perceptive point of view of agency theory, the executive directorates stand as agents to the known shareholders, and on the other hand, the nonexecutive and independent directors are indebted to the shareholders and this chain effect mandates the BOD to voluntarily disclose more corporate news to minimize information that is asymmetry [20]. From a clearer note on the theoretical foundation stated above, the current findings suggested the following hypotheses between CSRD and CG.

\subsection{Board Characteristics}

\subsubsection{Board Size}

It has been revealed by a couple of research in the past that larger boards were positively associated with CSRD $[4,42]$, as boards of larger nature contributed to impact positively to the reputation of the company and were characterized with high proficiency of knowledge and generosity and magnificent interests rate capable to enhance better the demand of CSR and ensuring uppermost transparency. Again, large boards possess the potential to add value to a corporate reputation for the fact that these could be attached to a more complex nature of expertise, stakeholder representation and knowledge. The equally an assurance of well-represented CSR through the diversity of stakeholders on boards, thereby appeal to task larger boards to fully engage the CSRD [46].

For a clearer picture of this fact, the study of Zaid et al. [57] indicated a positive impact on the ability of the board's size to disseminate information by satisfying expectations of stakeholders where transparency and information disclosure are enhanced. In another study by Donnelly and Mulcahy, [11] in Irish, the authors claimed that the magnitude of the board together with its clarity was related positively to the selected companies in Irish. Conversely, the study of $[33,44]$ failed to identify a little relationship between the CSRD and the size of the board. It becomes necessary to investigate the potential characteristics of CSRD and the size of the board. Thus, the hypothesis below was suggested.

H1: A positive relationship between board size and the level of corporate social responsibility disclosure.

\subsubsection{Board Independence}

The board as a shareholders' agent could enhance vis-a-vis the presence of an independent directorate. The disintegration of ownership and management is the basic behind the notion of agency theory. It is, however, believed that independent directors perform their duties of monitoring effectively. The Independent directors also stand to minimize the risk of conflict of interest between every party involved with full expectation to perform rigorously board y to the best interest of shareholders of the companies. Other authors who worked on agency theory claimed that a board characterized by the higher figure of non-executives members might carry out efficiently the duty of monitoring the top management and to ensure the interest of both the shareholders and other stakeholders are met by which is capable of averting any form of misunderstanding with the managers at the top. In addition to this, the dependency theory of resources suggested directors and revealed more information to their firms relating to legitimacy and resources, which in the long run ensure the better managerial process in decision making and then bring about an improved firm's performance [25].

The characteristics aspect of any governance of the corporate lies upon the independence of boards, as the directorate of independent nature, exists to protect the interest of both shareholders and stakeholders [22]. Research from previous studies propelled the boards' better decisions making process with the assistance of an independent director, and the strategy of CSR and disclosure adoption [14,57]. For this reason, establishments with a larger board of independence nature are more likely to tend to foster safety to the directors of CSR [27]. It must be known that CSRD does increase with the increasing magnitude of independent directorates on board [57]. This is because the independent nature of management could positively have affected the potential of CSR in their roles [29]. It can be observed that some other research did not reveal any relationship between the CARD and independent directors from their findings [12]. Meanwhile, some studies made by [57] discovered a positive effect in the context of governance. It thus becomes necessary to investigate if the independent nature of the board could affect the CSRD status. Thus, this 
hypothesis (H2) was set up.

H2: A positive relationship between board independence and the level of corporate social responsibility disclosure.

\subsubsection{Chair/CEO duality}

One of the prime aims of agency theory, as suggested, is to protect the interest of the managers, which is likely to affect the levels by which the activities of CSR and CSR disclosure are being manifested. The duality of CEO could be observed as an indicative and as a tool of managerial power in this context. The CEOs tend to be nominated to chair the boards of directors under a successful and good track record or if they have been able to better control a larger proportion of the shares to the firms [24]. Moreover, the board's agenda can be set forth by chairing the boards of directors and providing the tendency to influence provided data to the other members of the board. The CEOs also acting as the chairs have the power to keep to themselves crucial information most especially from those not party to the executive of the institution as clearly revealed [21,35]. The chairperson can act to deactivate the role of CEOs to influence the appointment of the board that could favour them [21]. On this note, the non-executive directors could agree on the decisions made by management against their better judgment, simply because they tend to avert any form of confrontations with their CEOs endowed with more powers. Evidence can be traced to an instance to retain their position or level of the board [10]. An experimental study by [14] suggested that attention of the boards of directors to monitor effectively affected negatively by the CEO duality and the degree of voluntary disclosure [14].

Based on the earlier empirical studies, suggestions have been made on executive remuneration in the United State holding banks at a sensitive increasingly risk, and this has been encouraging directors to consider many risks to expand their pay on a short-term basis. The findings indicated the sensitive risk of CEO's pay in the bank of United State of America holding companies which significantly increased between the year 1992 and 2008 and this phenomenon was ascribed to an increasing level of risk taken by the bank. On a similar note, the work of [14] revealed that between the years 1993 and 2007, the CEOs of United States of America banks made use of risky business transactions increasingly, as the level of equity-based pay for their performance contracts got a rise. It was however suggested that the inclination of a typical manager to minimize their risk exposure in protecting human capital was eroded by the system put in place of the pay packages of their executives. As there is a reduction of firms' risk profiles by CSR engagement disclosure $[51,52,53]$, the CEOs could perceive CSR reporting as a negative factor to maximize their indemnity.

Again, powerful CEOs can make use of CSR to improve their interests together with their moral convictions, instead of shareholders and other stakeholders' interests; there is a tendency for them to feel reluctant in providing a process that is comprehensive enough and high-quality disclosure of CSR. As the saving of data keeps rising, then also the external control becomes effective as this could reach out to investors, business press and financial analysts [23]. Also, it was noted that the public, powerful CEOs and other key stakeholders could develop an initiative to influence CSR and voluntary disclosure. Assumed that, the evolution of executive indemnity in banks during the last 15 years and the capability of CEOs, similarly who act as chairpersons of the boards of employers could affect the performance of board behaviour, it is expected that:

H3: A negative relationship between the chair/CEO duality and the level of corporate social responsibility disclosure.

\subsubsection{Foreign members of the Board}

The activities of foreign members can positively influence how transparent and willingness of members commit themselves to good governance as corporate bodies. As again stated, Grassa [16], These members also tend to behave more autonomously in gaining complete control over company leverage while also contributing significantly to CSR indecency. A board characterized by directors that is foreigners board, with knowledgeable with highly qualified members, could demand highly proficient CSRD as disclosed [43]. Bangladesh as a case sample, directors who are foreigners with a similar nature of foreign ownership is becoming more affiliated to the board because of the developmental growth rate under the multinational ventures [43]. At the same time, incessant and steady growth performance in the economy along with the level of directors (foreigners) board remains limited based on analysis made. Foreign managers, with their diverse experience, are acceptable to stimulate greater disclosure and oversight actions over management decisions on the Jordanian board. This could later drive the board towards the best practice of CSR disclosure. From the concise discussion, the following hypothesis is suggested.

H4: A positive relationship among the foreign members of the board and the level of corporate social responsibility disclosure.

\subsubsection{The Board of Accounting Experts}

It is critical to know that accounting experts should possess professional degree qualifications in their respective areas of specialization. Expatriates in the accounting of a given company must always be focused on the profit-making ability of the firm rather than sustaining it [49]. As an example, Khan et al. [33] postulated that there is a need for accounting experts to strive in maximizing the total profit of the company and preventing corporate managers from the potential of investing in CSR. In another research finding, experts in accounting have the potential to minimize the level of corruption at the management level and make sure that every type of 
disclosure is well organized [40]. Parts of their activities are also in line to ensure a positive relationship between the CSRD and the diversity of the educational board. Results from another study carried out in Pakistan postulated an insignificant relationship between board educations. It is requested for the directorate board to implement an ideal understanding of accounting in compliance with the worldwide standards to ensure better quality supervision and effective consultancy [33]. It is impossible to meet up with the compliance of the majority of these standards in case there is a lack or limited professional knowledge to handle such a task. Hence, the current study assumes that the board had access to an accounting expert team that has a huge ability to influence CSR disclosure positively.

H5: A positive relationship among the Board of Accounting Experts and the level of corporate social responsibility disclosure.

\subsubsection{Female members of the Board}

Gender is also an important factor to consider in the success of a financial institution. Findings in the past agreed to the fact that the presence of female gender as board member positively influenced the quality of CSRD. According to Liao, Luo, and Tang [38] where 568 firms were examined from fifteen (15) different nations, it was revealed that the place of women on boards stood out to be one of the leading factors to diffuse information, and there was an affirmation of the well-improved status of eco-friendly and more transparency was seen with the manifestation of female gender with directorate status on boards among British companies. This is in line with the study of Khan et al. [33], they also believed that, when compared to their male counterparts, females were more actively engaged in social behaviours. Similarly in China, the social performance companies were observed to be improved better due to the members of female genders there present on boards and this revelation was done by McGuinness et al. [42]. Considering the facts from much literature, this present study has been able to deduct the high potential of women's existence to positively affect CSRD on boards.

H6: A positive relationship among the female members of the board and the level of corporate social responsibility disclosure.

\subsubsection{Audit Committee}

The size of the audit committee could be termed as the total number of members present in it. Putting into consideration the valuable message of the ASX corporate governance council [3], the component of an audit committee must have a minimum of three (3) members with better accounting and legal knowledge that are efficient enough to address properly the monitoring and reporting activities, like that of CSRD. Audit committees of larger nature possess reasonable strength and expertise that are highly diversified to achieve the expected monitoring process needed by CSRD expectation [33]. The committee of extra-large status however brings about added costs such as the possible cost of poor coordination, communication, and failure in control over normality [31]. Another scientific finding observed a free-rider problem that could arise with the presence of larger committees by also bringing about responsibilities capable to destabilize CSRD impacts [37]. On this note, this study suggests the hypothesis below.

H7: A positive relationship among audit committee size and the level of corporate social responsibility disclosure.

\section{Methodology of Research}

\subsection{Data}

The fact revealed that the Amman Stock Exchange (ASE) comprises 240 companies allotted to 3 sectors which are Industry, Financial and Services. This current research made use of the banking sector as a sample size to be studied for the reason being considered relevant in the Jordanian capital market. In 2019, the banking industry occupied approximately $44 \%$ of the total market capitalization in Jordan according to findings made by JCB from published statistical data. Again, the banking industry contributed meaningfully to the JDP of Jordanians by approximately $51 \%$. It was remarkably noted that the assets of the total banks represented $80 \%$ of the overall market assets in the year 2019. Further to this, out of 16 listed banks, 14 banks were observed to be among the biggest 20 listed companies in that market thereby making a signal that the sector of the banking industry was the largest in Jordan as a nation.

Valuable data has been obtained from the banks in Jordan for a number of 10 years (from 2010 to 2020). Choosing the year 2020 was due to the fact that the year is so recent to conduct this investigation. As a result, this could serve as a helpful hand in capturing a better image on the CSRD. Thus, the year 2010 was chosen to make it decade standing for the fact that, unpublished annual reports were to be revived as they were manually obtained from the selected banks. The study made use of 155 annual reports of data collection out of 155 reports per annum. It must be noted that 15 annual reports have been obtained manually from the banks while 140 annual reports were downloaded via an online medium.

\subsection{Corporate Social Responsibility Disclosure Index}

The CSRD has been termed as voluntary disclosure on the related activities to the personnel, market arena, social and environmental factors. The goal of such disclosure is to keep corporations accountable in the communities they operate in while also instilling beneficial effects on all parties engaged in the business. According to Holt [26], CSRD is a disclosure index that measures the importance of a company's successes to its stakeholders, which include 
consumers, government, workers, regulators, investors, and the whole society. This explains why the level at which CSRD is seen is so important in the present research. In line with the work of Unerman [54], the quantity issue renders assistance in capturing a richer picture of the CSRD. Certain research from the past thereby considered the quantitative nature of CSRD as a proxy to the qualitative nature of CSRD as deducted by $[9,18,34$, 45,54].

Conversely, the argument from some other researchers revealed slight differences between the method of quantity disclosure and the method of quality disclosure and subsequently observed double approaches of high correlation based on the analysis of Hooks \& van Staden [28]. On note of this, this research made use of contextual evaluation as a research model in capturing the CSRD quantity. The content analysis was widely adopted previously in some research, and it was proved as an effective means or model to investigate CSRD. This study constructed a model of CSRD checklist spanning four dimensions of CSR which include the following components: the dimension of an employee, the dimension of community, the dimension of the marketplace and the dimension of environment. A total number of 100 disclosed items were equally included in the considered checklist. To construct the CSR checklist, a model was adopted from earlier research studies from developing nations and emphasis could be made from the following authors such as [2,15,22], and in the banking, industry references can be traced to work of $[5,14]$ Following some modifications to capture the most improved checklist of CSR in the banking industries. This modification is a necessary tool to develop the banking environment of Jordan.

\subsection{Model Development}

The regression model of Ordinary Least Square (OLS) was considered for use in evaluating the possible connection between independent variables (IV) and dependent variables (DV). The approach of GMM regression was used to detect the issue of endogeneity and observe if the observed linkage from OLS was firmly fitted or not. The equation below, therefore, is an express model adopted in this study:

$$
\begin{gathered}
\text { CSRDI }_{i t}=a_{0}+\beta_{1} B B S I Z E_{i t}+\beta_{2} B I N D_{i t}+\beta_{3} C D U A L_{i t} \\
+\beta_{4} F B M_{i t}+\beta_{5} A E_{i t}+\beta_{6} F B M_{i t}+\beta_{7} A U D I T_{i t}
\end{gathered}
$$

Where, CSRDI $=$ Corporate social responsibility disclosure index received by each sample bank; $\alpha 0=$ the constant, $\varepsilon i t=$ the error term, $\beta 1$ to $\beta 7=$ the coefficients of the variables defined in Table 1 , and ' $i$ ' and ' $t$ ' = the number of banks and period respectively.

\begin{tabular}{|c|c|c|}
\hline VARIABLE & ACRONYM & MEASUREMENT \\
\hline \multicolumn{3}{|l|}{ Dependent Variables } \\
\hline CSR disclosure index & CSRDI & $\begin{array}{l}\text { CSRDI was developed by using the scores of " } 1 \text { " if the company } \\
\text { discloses the corporate social responsibility items and " } 0 \text { " if it is not }\end{array}$ \\
\hline \multicolumn{3}{|l|}{ Independent Variables } \\
\hline Board size & BSIZE & $\begin{array}{l}\text { The natural logarithm of the total number of members of the board } \\
\text { of directors }\end{array}$ \\
\hline Independent members of Board & BIND & Proportion of independent members \\
\hline Chair/CEO duality & CDUAL & $\begin{array}{l}\text { Dummy variable takes one if the chairman does not hold the } \\
\text { position of CEO, otherwise zero. }\end{array}$ \\
\hline Foreign members of Board & FBM & Number of Foreign members of Board \\
\hline Board of Accounting Experts & $\mathrm{AE}$ & $\begin{array}{l}\text { On the board, there are a number of accounting professionals with } \\
\text { professional degrees such as CA and CMA. }\end{array}$ \\
\hline Female members of Board & FBM & Number of female managers on the board \\
\hline Audit Committee & AUDIT & Number of audit committee members \\
\hline
\end{tabular}

Table 1. Definitions of the variables

\begin{tabular}{|c|c|c|c|c|c|}
\hline & Employee & Community & Market & Environment & Overall \\
\hline Observation & 155 & 155 & 155 & 155 & 155 \\
\hline Mean & .53 & .43 & .57 & .20 & .47 \\
\hline Minimum & .020 & .109 & .000 & .014 & .21 \\
\hline Maximum & .993 & .966 & .993 & .932 & .83 \\
\hline Std. Deviation & .319 & .549 & .273 & .186 & .109 \\
\hline No. Items & 31 & 32 & 25 & 12 & 100 \\
\hline
\end{tabular}

Table 2. Descriptive statistics of CSRD 
Table 3. Descriptive Statistics

\begin{tabular}{|c|c|c|c|c|c|}
\hline Variables & Observation & Mean & Minimum & Maximum & Std. Deviation \\
\hline CSRDI & 155 & 0.742 & 0.612 & 0.925 & 0.014 \\
\hline BSIZE & 155 & 8.102 & 5.000 & 18.000 & 2.014 \\
\hline BIND & 155 & 0.051 & 0.000 & 0.269 & 0.060 \\
\hline CDUAL & 155 & 0.161 & 0.059 & 0.221 & 0.012 \\
\hline FBM & 155 & 0.110 & 0.000 & 0.180 & 0.089 \\
\hline AE & 155 & 46.084 & 8.000 & 183.000 & 0.216 \\
\hline FBM & 155 & 0.053 & 0.000 & 0.160 & 0.012 \\
\hline AUDIT & 155 & 0.890 & 0.000 & 1.000 & 0.016 \\
\hline
\end{tabular}

\section{Results}

\subsection{Descriptive Analysis}

As indicated in Table 2, the disclosure on the average index from the banking industry in Jordan represents $47 \%$. And the highest disclosure rate represents $83 \%$ while $21 \%$ stands for the lowest which implies that a certain number of banks in Jordan are featured with a good level of disclosure. Meanwhile, a contrary indicator was shown at a level lower in CSRD could probably be due to a low level of activities by the CSR or a poor experience in the ability of CSR to report. A comparative observation was identified with this level of disclosure to the CSRD level considering some sectors in banking industries form parts of developing nations like Pakistan (0.47) as recorded by Sharif \& Rashid [53] but tuned out to be higher level (15\%) than banks selected from Kenya as revealed by Barako \& Brown [5]. Additionally, from another study carried in Bangladesh, a percentage of $6.41 \%$ was recorded which is equally lower from the comparative analysis [53]. Further to this, some selected research in Malaysia in accordance with the work of [15], equally revealed a relatively low level of CSRD (25.2\% and $13.9 \%$ in that respect). The analysed data recorded in Nigeria was 22\% for CSRD level [55].

With no doubt, the disclosure ascribed to the market dimension recorded the highest mean value of 0.53 as compared to that of the environmental dimension which was recorded low (0.20). The highest means value of 0.57 has been observed considering the employee dimensional index factor, while the community dimension recorded 0.43 , which is quite low. The poor level related to the environmental dimension was probably due to the less attention that was paid to the environment by overlooking it. A further reason was equally explained to the fact that the environmental dimension might experience a failure of environmental institutions to exist which later became accountable to lower pressure arising from stakeholders. And again, generally, the banking and financial industry see themselves as eco-friendly businesses thereby bringing about negligence to any activity related to the environmental dimension. On this note, the banks in Jordan have been identified to put a consideration into disclosing their activities on the market dimension as compared to the environment, and this could be said to the banks that have been considering reporting such activities as a model to advertise an image buildings medium rather than social obligations.

From the descriptive data, as shown in Table 3, the average rate value of CSRDI was recorded $74.21 \%$, meanwhile, the standard deviation was seen not to be considered. This indicated that the CSRDI of commercial banks in Jordan was described as high. The commercial banks in Jordan have been known to strictly adhere to the rules of law backing the CSRDI activities. Generally, the outputs of the independent variables based on descriptive statistical analysis accurately reflected the present nature of the Jordanian banking industry most especially when the members of the average board size comprised of 8.10 , with independent members of the board of $5.11 \%$, then $16.14 \%$ of the average of chair/CEO duality, $10.69 \%$ of foreign members of board, $46.08 \%$ rate of the average number of experts in accounting, 5.38\% was observed for female members of the board, and finally $89.05 \%$ rate of the audit committee. The independent variables were therefore observed to be negligible in standard deviations.

\subsection{Correlations}

The correlations coefficient considering the pair of variables as adopted in this research is shown in Table 4. The interrelationship between two negative or positive variables in each degree of significance was explored. The CSRD was observed to be positively correlated to the board size, committee on audit and foreign members of the board. The outcome from this study simply implies, as the total board size, foreign members of the Board and committee on audit go higher, the higher the possibility to disclose CSR becomes. 
Table 4. Correlation

\begin{tabular}{|c|c|c|c|c|c|c|c|c|}
\hline & CSRDI & CSRDI & CSRDI & CSRDI & CSRDI & CSRDI & CSRDI & CSRDI \\
\hline CSRDI & 1 & & & & & & & \\
\hline BSIZE & .501 & 1 & & & & & & \\
\hline BIND & -.284 & -.302 & 1 & & & & & \\
\hline CDUAL & -.304 & -.290 & .410 & 1 & & & & \\
\hline FBM & .521 & .384 & .310 & .410 & 1 & & & \\
\hline AE & -.316 & .401 & .260 & .301 & .473 & 1 & & \\
\hline FBM & .401 & .312 & .402 & .248 & .254 & .410 & 1 & \\
\hline AUDIT & .547 & .314 & .415 & .406 & .321 & .314 & .421 & 1 \\
\hline
\end{tabular}

**. Correlation is significant at the 0.01 level. *. Correlation is significant at the 0.05 level.

\section{Regression Results}

Based on the results from the OLS regression model as presented in Table 5, the Adjusted R-squared was seen to be 0.7153 . This revealed the percentage of the independent variable to be 0.7153 of the variation of the DV. The level at which significance of probability (F-statistics) was observed as 00000 , which was less than $5 \%$. It should be known that the result comprises of three (3) variables influencing similar directions on CSRDI with the inclusion of BSIZE and FOREIGN and AUDIT. However, the approach of regression is revealed below:

$$
\begin{gathered}
C_{S R D I_{i t}}=0.491+0.362 \text { BSIZE }_{i t}-0.014 \text { BIND }_{i t^{-}} \\
-0.106 C^{-} D U A L_{i t}+0.463 \text { FBM }_{i t}-0.084 A E_{i t}{ }^{+} \\
+0.147 \text { FBM }_{i t}+0.511 A U D I T_{i t}
\end{gathered}
$$

Table 5. The effect of board characteristics on corporate social responsibility disclosure

\begin{tabular}{|c|c|c|}
\hline Variables & Coefficients & P-value \\
\hline Constant & .491 & $.000^{* *}$ \\
\hline BSIZE & .362 & $.000^{* *}$ \\
\hline BIND & -.014 & .504 \\
\hline CDUAL & -.106 & .360 \\
\hline FBM & .463 & $.000^{* *}$ \\
\hline AE & -.084 & .712 \\
\hline FBM & .147 & .140 \\
\hline AUDIT & .511 & $.000^{* *}$ \\
\hline R squared & \multicolumn{2}{|c|}{.806} \\
\hline R adjustment & \multicolumn{2}{|c|}{14.08} \\
\hline F-statistics & \multicolumn{2}{|c|}{$.000^{* *}$} \\
\hline Probability & \multicolumn{2}{|c}{} \\
\hline
\end{tabular}

Not (1): **,*** denote, $5 \%$ and $1 \%$ significant levels, respectively.

A positive relationship has been observed in Table 5 projecting the board size, committee on audit, foreign members of the board and the CSRDI at a level of $1 \%$. This means that the bigger the board, the more foreign members on the board, and the bigger the audit committee, the more likely it is to report CSR efforts. The output revealed in this study is in line with the results obtained from similar previous research as the case study from the work of $[14,30,32,41]$, as the BSIZE was seen to positively influence the CSRD activities. This explains why as a team of the board becomes much, then the appropriate views which are much better together with opinions in deciding to disclose data it becomes. Moreover, both FOREIGN and CSRDI were tagged to have a similar meaning and this output agreed with the work of Jahid et al. (2020). It has also been revealed that members of the foreign nature of the board tend to follow due process and abide by the protocol; therefore, their existence on the boards would promote CSRDI performance. Also, an improved level of CSRDI of commercial banks is manifested due to the excellent role played by the audit committee. However, no significant difference has been observed based on the outputs between the members of independent nature of board Chair/CEO duality, members of the board of foreign status, experts in accounting, female genders of the board and the CSRDI. Signs of coefficient linked to the variables in question were not consistent as expected.

\subsection{Results Discussion}

Of all the characteristics features of the board, the size of the board remains so significant and plays a vital role in CSRD passively. Board sizes of larger nature may comprise well-diversified, knowledgeable, and expert directors. Larger boards rendered a positive significant difference to the reputation of a company. This is because of its combined effects of bigger interests and higher skills that can improve CSR as a necessary tool coupled with better transparency. In the same vein, the findings further suggested that companies must try their possible best to expand board size because extended boards could render more help to CSRD achievement. It was later noted that the executives should also put into consideration both the benefits and costs of a board characterized with huge size as the overall costs are higher compared to a board of smaller size. In this vein, the existence of independent board members possesses the ability to improve the quality of the decision-making process, most especially when it comes to and CSRD together with CSR in decision-making 
activities and this claim could also be traced to the work of [19,57].

Banks that are characterized with a greater number of foreign directors were observed to significantly influence the compatibility of CSRD with past studies carried out [43]. The foreign members projected better growing interest for share investment, and as they exist on boards with highly diversified knowledge bring about improvement in the long-run effect. Therefore, there is a need to disclose more and control over the board in their decision-making process, as this could eventually influence the board to disclose more information on CSR and this was supported by the work of Grassa [16]. Therefore, it is confirmative that banks with larger board size, audit committee, and foreign directors could lead to CSRD that are higher.

The size of an audit committee remains critical as discussed earlier to the success of CSRD. A corporate audit committee needs to be accurate in their decision making over the CSRD and CSR because of its responsibility to formulate sustainable growth of business strategies and proper monitoring in making use of the company's assets. Some of the past research revealed a helpful relationship between the CSRD and the size of the audit committee and this connotes with the works of [33]. In light of this, the audit committee was held to be responsible for making sure of integrating better professionalism of financial statements and improved operational performance, but inclined in terms of profit sustainability. It was also discovered that; it was not possible for audit committees of the banks to manifest any change to CSRD and CSR. Thus, an audit committee was found to contribute meaningfully as a watchdog in authenticating the potential of the company to improve more on CSRD. Hence, the Central Bank should set up rules capable to mandate it to the banks to encourage more female genders to the boards alongside larger audit committees and board size.

Curiously, an insignificant effect was observed among experts in the accounting field on the CSRD and boards in the current study and this claim agreed to the work of Khan et al. [33]. It was further found out that the moderate level of experts of accounting on the boards was highly insignificant to the board in deciding their process. Additionally, expatriates in accounting used to emphasize performance characteristics of the financial system, instead of taking note of CSR also. This act with no doubt distracts the management from contributing their quota to CSR improvement. Consequently, no significant difference has been observed based on findings obtained between the foreign members of the board, independent members of board Chair/CEO duality, accounting experts, the CSRDI and female members of the board. The signs of the coefficients with the variables in issue, however, were not as constant as predicted.

Jordan as a nation is attempting to integrate the worldwide economic style and locally to comply with necessary rules guiding the CSRD. This makes it important to have pioneered the ability to comply with regulations related to CSRD, especially in the banking industry, which is the leading financial firm in the economy. With this, fairness is ensured with stakeholders in a way of harmonizing the system between community social and economic growth. Hence, it is necessary for the board under the influence of commercial banks and to create more meaningful awareness for society and community. In a plan to establish sound sustainable development rather than just immediate benefits, the board must adopt a long-term strategy for the fact that CSR could bring up the irrelevant value that can increase the confidence and credibility of stakeholders. More so, the Jordanian central bank is expected to strengthen the monitoring system of CSRD commercial banks in Jordan to improve the quality of information. Again, to improve the board's awareness of CSR, sound advocacy and consultation is required to be raised by the Central bank. Also, the Central bank must put into consideration additional poetical styles in terms of CSRD for commercial banks in their ability of credit rating. However, bank central must on regular basis instill good monitoring activity so as not to indulge any sanction in the case there no CSRD is not guaranteed by commercial banks.

\section{Conclusions}

Conclusively from the trend of economic globalization, the study of CSR remains important to the success of the banking industry and business improvement. Every organization should be able to handle the relationship between the factor of economic, social growth and economic development to bring about harmony among the stakeholders and other parties involved. The current study has been able to investigate the level of CSRD from a selected developing country with Jordan included. The study went ahead to explain the possible effects of corporate governance on the rate of CSRD concerning the financial sector, which has not been given more consideration by the studies carried out in the past. This current study, however, employed panel data with 155 banks for known years from sixteen (16) banks from 2010 to 2020. The adopted variables in this study were able to address the reason for the low level of CSRD in Jordan. The prevalence of CSRD was generally modest, with an average percentage value of $47 \%$. The size of the board (BSIZEs) and foreign members of the board (FOREIGN), as well as the audit committee (AUDIT), were shown to have an impact on the CSRD in this study. To a well-improved CSRD, the commercial banks of Jordan must create more awareness of the potential of CSR to strengthen the banking sector of Jordan. The overall efforts would in turn contribute meaningfully to the quality of information to compete with the novel trend of international demand.

Furthermore, since their limited findings on issues 
related to CSRD in developing countries and Arabian nations, this study becomes relevant added values in the efforts to establish good financial knowledge (Barako \& Brown, 2008). Thus, this study was capable of establishing some facts about CSRD in each banking system of a developing country (Jordan). This study further consulted more literature to establish a novel idea to improve corporate governance by making use of accounting expert's variables. However, the introduction of an expatriate in accounting was an exceptional practice in the Jordan context.

Finally, it is not doubtful that the present research projected a good image to many groups of stakeholders and shareholders like those of government regulators, CSR agencies and potential investors. The poor level of disclosure may attract more attention from the regulators which could motivate the banks and foster enhanced practices of CSR and disclosure. Also, the regulators could set forth a guideline for CSR to report on environmental and social activities based on what the country demands. Additionally, it is expected of the government to be strict in abiding by the rules of law to remain relevant to the governmental-linked banks. Governmental ownership in Jordanian banks is determined to be quite low, implying that the Jordanian government must continue to encourage linked banks and other banks to pay more attention to societal demand. Future studies on board committees such as the executive committee, corporate governance committee, and risk management committee are required, as is the need to address ethics variables as key elements in improving corporate disclosure and openness in developing nations.

\section{REFERENCES}

[1] Akanfe, S. K., Michael, S. O. \& Bose, A. D., "Determinant of Corporate Social Responsibility Disclosure in Nigeria," International Journal of Academic Research in Business and Social Sciences, 7, 565-580. 2017.

[2] Amran, A., \& Devi, S. S., "The impact of government and foreign affiliate influence on corporate social reporting the case of Malaysia," Managerial Auditing Journal, 23(4), 386-404. 2008. 2008.

[3] ASX Corporate Governance Council., "Corporate governance principles and recommendations," with 2010 amendments (2nd ed.). Australian Securities Exchange. 2010.

[4] Bae, S., Masud, M., \& Kim, J., "A cross-country investigation of corporate governance and corporate sustainability disclosure: A signalling theory perspective," Sustainability, 10(8), 2611. 2018.

[5] Barako, D. G., \& Brown, A. M., "Corporate social reporting and board representation: evidence from the Kenyan banking sector," Journal of Management \& Governance, 12(4), 309-324.2008.
[6] Becht, M., Bolton, P., \& Röell, A., "Corporate governance and control,". Handbook of the Economics of Finance, 1, 1-109. 2003.

[7] Bowen, H. R., "Social Responsibilities of the Businessman". New York, NY: Harper \& Brothers. 1953.

[8] Branco, M. C. \& Rodrigues, L., "Factors influencing social responsibility disclosure by Portuguese companies," Journal of Business Ethics, 83(1), 685-701. 2008.

[9] Deegan, C., \& Gordon, B., "A study of the environmental disclosure practices of Australian corporations," Accounting and Business Research, 26(3), 187-199.1996.

[10] Dey, A., "Corporate Governance and Agency Conflicts" Journal of Accounting Research, 46(5), 1143-1181.2008.

[11] Donnelly, R., \& Mulcahy, M., "Board structure, ownership, and voluntary disclosure in Ireland," Corporate Governance: An International Review, 16(5), 416-429. 2008.

[12] Esa, E., \& Anum Mohd Ghazali, N., "Corporate social responsibility and corporate governance in Malaysian government-linked companies," Corporate Governance: The international journal of business in society, 12(3), 292-305. 2012.

[13] Freeman, R. E., "Strategic management: A stakeholder approach," New York, NY: Cambridge University Press. 2010.

[14] Ghabayen, M. A., Mohamad, N. R. \& Ahmad, N., "Board characteristics and corporate social responsibility disclosure in the Jordanian banks," Issues of the Journal, 12(1), 84-100.2016.

[15] Ghazali, N. A. M., "Ownership structure and corporate social responsibility disclosure: some Malaysian evidence," Corporate Governance, 7(3), 251-266.2007.

[16] Grassa, R., "Corporate governance and credit rating in Islamic banks: Does Shariah governance matters? " Journal of Management \& Governance, 20(4), 875-906.2016.

[17] Grassa, R., Chakroun, R., \& Hussainey, K., "Corporate governance and Islamic banks' products and services disclosure," Accounting Research Journal, 31(1), 75-89. 2018.

[18] Gray, R., Kouhy, R., \& Lavers, S., "Corporate social and environmental reporting: a review of the literature and a longitudinal study of UK disclosure," Accounting, Auditing \& Accountability Journal, 8(2), 47-77. 1995.

[19] Guerrero-Villegas, J., Pérez-Calero, L., Hurtado-González, J., \& Giráldez-Puig, P., "Board Attributes and Corporate Social Responsibility Disclosure: A Meta-Analysis," Sustainability, 10(12), 4808. 2018.

[20] Gul, F. A., \& Leung, S., "Board leadership, outside directors' expertise and voluntary corporate disclosures," Journal of Accounting and public Policy, 23(5), 351-379. 2004.

[21] Haniffa, R. M., \& Cooke, T. E., "Culture, corporate governance and disclosure in Malaysian corporations," Abacus, 38(3), 317-349.2002.

[22] Haniffa, R. M., \& Cooke, T. E., "The impact of culture and governance on corporate social reporting," Journal of Accounting and Public Policy, 24(5), 391-430. 2005. 
[23] Healy, P.M. and Palepu, K.G., "Information Asymmetry, Corporate Disclosure, and the Capital Markets: A Review of the Empirical Disclosure Literature," Journal of Accounting and Economics, 31(1-3), 405-440.2001.

[24] Hermalin, B.E. and Weisbach, M.S., "Endogenously Chosen Boards of Directors and Their Monitoring of the CEO," American Economic Review, 88(1), 96-118.1998.

[25] Hillman, A. J., Cannella, A. A., \& Paetzold, R. L., "The resource dependence role of corporate directors: Strategic adaptation of board composition in response to environmental change, " Journal of Management studies, $37(2), 235-256.2000$

[26] Holt, D., "Managing the interface between suppliers and organizations for environmental responsibility-an exploration of current practices in the UK," Corporate Social Responsibility and Environmental Management, 11(2), 71-84. 2004.

[27] Hong, B., Li, Z., \& Minor, D., "Corporate governance and executive compensation for corporate social responsibility," Journal of Business Ethics, 136(1), 199-213. 2016.

[28] Hooks, J., \& van Staden, C. J., "Evaluating environmental disclosures: The relationship between quality and extent measures, " The British Accounting Review, 43(3), 200-213.2011.

[29] Huynh, Q. L., "A Triple of Corporate Governance, Social Responsibility and Earnings Management," Journal of Asian Finance, Economics and Business, 7(3), 29-40. 2020.

[30] Jahid, A., Rashid, H. U., Hossain, S. Z., Haryono, G. S. \& Jatmiko, B., "Impact of Corporate Governance Mechanisms on Corporate Social Responsibility Disclosure of Publicly-Listed Banks in Bangladesh," Journal of Asian Finance, Economics and Business, 7(6), 61-71.2020.

[31] Jensen, M. C., "The modern industrial revolution, exit, and the failure of internal control systems," Journal of Applied Corporate Finance, 22(1), 43-58. 2010.

[32] Jizi, M., Salama, A., Dixon, R. \& Startling, R., "Corporate governance and corporate social responsibility disclosure: evidence from the US banking sector," Journal of Business Ethics, 125(4), 601-615. 2014.

[33] Khan, I., Khan, I., \& Saeed, B. B., "Does board diversity affect quality of corporate social responsibility disclosure? Evidence from Pakistan," Corporate Social Responsibility and Environmental Management, 26(6), 1371-1381. 2019.

[34] Krippendorff, K., "Content Analysis: An introduction to its methodology, London: Sage" 92. 1980.

[35] Krishnan, G. and Visvanathan, G., "Do Auditors Price Audit Committee's Expertise? The Case of Accounting versus Non-accounting Financial Experts," Journal of Accounting, Auditing and Finance, 24(1), 115-144.2009.

[36] Kuzey, M. \& Uyar, C. K. A.,"The impact of ownership and board structure on corporate social responsibility (CSR) reporting in the Turkish banking industry," The International Journal of Business in Society, 15(3), 357-374.2015.

[37] Li, J., Mangena, M., \& Pike, R., "The effect of audit committee characteristics on intellectual capital disclosure," The British Accounting Review, 44(2), 98-110. 2012.

[38] Liao, L., Luo, L., \& Tang, Q., "Gender diversity, board independence, environmental committee and greenhouse gas disclosure," The British Accounting Review, 47(4), 409-424.2015.

[39] Lindblom, C. K., "The implications of organizational legitimacy for corporate social performance and disclosure," Paper presented at the Critical Perspectives on Accounting Conference, New York, 1994.

[40] Masud, A. K., Rashid, H. U., Khan, T., Bae, S. M., \& Kim, J. D., "Organizational Strategy and Corporate Social Responsibility: The Mediating Effect of Triple Bottom Line," International Journal of Environmental Research and Public Health, 16(22), 4559. 2019.

[41] Matuszak, L., Rozanska, E. \& Macuda, M., "The impact of corporate governance characteristics on banks' corporate social responsibility disclosure: Evidence from Poland," Journal of Accounting in Emerging Economies, 9(1), 75-102. 2019.

[42] McGuinness, P. B., Vieito, J. P., \& Wang, M., "The role of board gender and foreign ownership in the CSR performance of Chinese listed firms," Journal of Corporate Finance, 42, 75-99.2017.

[43] Muttakin, M. B., Khan, A., \& Subramaniam, N., "Firm characteristics, board diversity and corporate social responsibility: evidence from Bangladesh," Pacific Accounting Review, 27(3), 353-372. 2015.

[44] Nguyen, T. M. H., Nguyen, N. T., \& Nguyen, H. T., "Factors Affecting Voluntary Information Disclosure on Annual Reports: Listed Companies in Ho Chi Minh City Stock Exchange," Journal of Asian Finance, Economics and Business, 7(3), 53- 62. 2020.

[45] Nielsen, C., "A content analysis of analyst research: health care through the eyes of analysts," Journal of Health Care Finance, 34(3), 66- 90.2007.

[46] Ntim, C. G., \& Soobaroyen, T., "Corporate governance and performance in socially responsible corporations: New empirical insights from a Neo - Institutional framework," Corporate Governance: An International Review, 21(5), 468- 494. 2013.

[47] Poudel, R. L., "Relationship between Corporate Governance and Corporate Social Responsibility: Evidence from Nepalese Commercial Banks," The Journal of Nepalese Business Studies, IX (1), 137-144. 2015.

[48] Qoyum, A., Mutmainah, L., Setyono, I. \& Qizam, J., "The Impact of Good Corporate Governance, Company Size in Corporate Social Responsibility Disclosure: Case Study of Islamic Banking in Indonesia," Iqtshadva, 10(1), 130-159. 2017.

[49] Rashid, M. H. U., Zobair, S. A. M., Chowdhury, M. A. I., \& Islam, A., "Corporate governance and banks' productivity: evidence from the banking industry in Bangladesh," Business Research, 13(2), 1-23. 2020.

[50] Rehma, Z. U., Zahid. M., Rahman, H. U., Asif, M., Alharthi , M., Irfan , M \& Glowacz , A., "Do Corporate Social Responsibility Disclosures Improve Financial Performance? A Perspective of the Islamic Banking 
Industry in Pakistan," Sustainability, 12(3302), 1-18. 2020.

[51] Salama, A., Anderson, K. and Toms, J.S., "Does Community and Environmental Responsibility Affect Firm Risk? Evidence from UK Panel Data 1994-2006," Business Ethics: A European Review, 20(2), 192-204.2011.

[52] Scholtens, B., "Corporate Social Responsibility in the International Banking Industry," Journal of Business Ethics, 86(2), 159-175.2008.

[53] Sufian, M. A., \& Zahan, M., "Ownership Structure and Corporate Social Responsibility Disclosure in Bangladesh," International Journal of Economics and Financial Issues, 3(4), 901-909.2013.

[54] Unerman, J., "Methodological issues: Reflections on quantification in corporate social reporting content analysis," Accounting, Auditing and Accountability Journal, 13(5), 667-680.2000.

[55] Uwuigbe, U., "An examination of the relationship between management ownership and corporate social responsibility disclosure: A study of selected firms in Nigeria," Research Journal of Finance and Accounting, 2(6), 23-29.2011.

[56] Zahari, A. R., Esa, E., Rajadurai, J., Azizan. N. A. \& Tamyez, P. F. M., "The Effect of Corporate Social Responsibility Practices on Brand Equity: An Examination of Malaysia's Top 100 Brands," Journal of Asian Finance, Economics and Business, 7(2), 271-280. 2020.

[57] Zaid, M. A., Wang, M., \& Abuhijleh, S. T., "The effect of corporate governance practices on corporate social responsibility disclosure," Journal of Global Responsibility, 10(2) 134-160.2019. 